\author{
UNIVERSIDADE DE SÃO PAULO \\ MUSEU DE ARQUEOLOGIA E ETNOLOGIA \\ PROGRAMA DE PÓS-GRADUAÇÃO EM ARQUEOLOGIA
}

\title{
ARQUEOLOGIA MARÍTIMA DE UM BOM ABRIGO
}

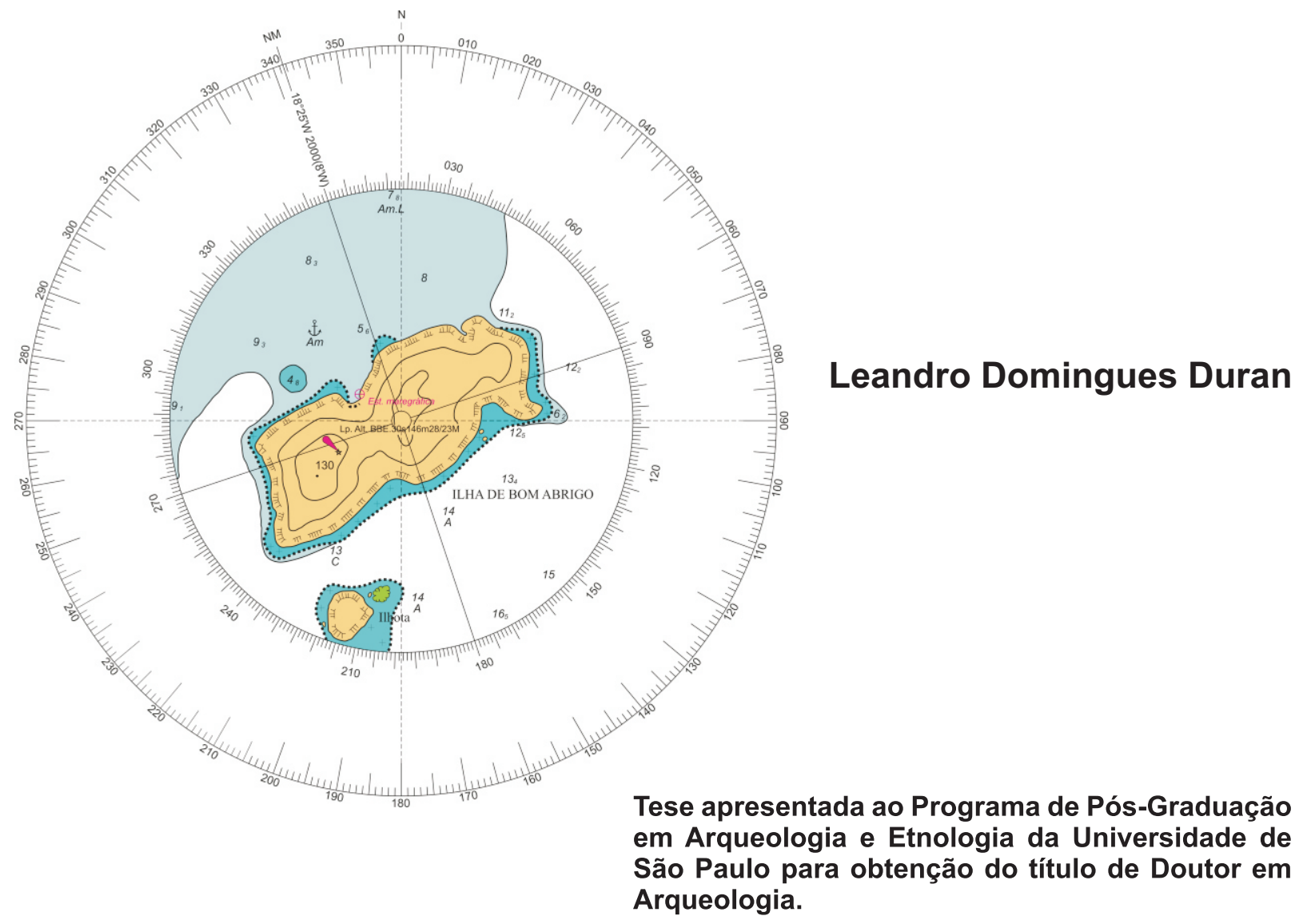

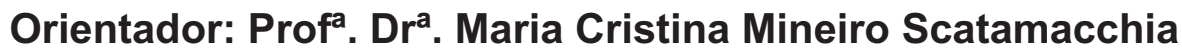

Linha de Pesquisa: Espaço e Organização Social 